\title{
Effect of embryonic treatment with oestradiol benzoate on reproductive morphology, ovulation and oviposition and plasma LH concentrations in female quail (Coturnix coturnix japonica)*
}

\author{
Emilie F. Rissman, Mary Ascenzi, Patricia Johnson and Elizabeth Adkins- \\ Regan
}

Department of Psychology, Department of Poultry and Avian Science, and Section of Neurobiology and Behavior, Cornell University, Ithaca, New York 14853, U.S.A.

\begin{abstract}
Summary. Quail eggs were injected on Day 10 of incubation with $0,5,10,20$ or $40 \mu \mathrm{g}$ oestradiol benzoate. Females hatching from these eggs were reared on a $16 \mathrm{~L}: 8 \mathrm{D}$ photoperiod and egg laying was recorded. Blood samples were taken at 37, 40, 43, 46, 49, 52, 55,58 or 61 days of age and LH concentrations were measured by a double-antibody radioimmunoassay. Birds were killed at 61 days of age; ovaries and oviducts were weighed and examined. Egg laying was greatly reduced by oestradiol benzoate treatment, but for birds that did lay, age at first oviposition was normal. LH levels were not affected by oestradiol benzoate treatment, and were highest at 40 and 49 days of age. Oestradiol benzoate had no effect on ovarian weight, number of follicles with diameter $>1 \mathrm{~cm}$, or number of post-ovulatory follicles. Oestradiol benzoate had a doserelated effect on the likelihood that females would have two oviducts, and for those females that had retained the right oviduct, the left oviduct was smaller than normal. Oestradiol benzoate-treated females were more likely to have ovulated yolks in the body cavity. Embryonic treatment with oestradiol benzoate therefore appears to inhibit egg laying by causing oviduct abnormalities, rather than by (as happens in mammals) inhibiting ovulation.
\end{abstract}

\section{Introduction}

Treatment of fetal or neonatal rodents with testosterone or oestradiol produces an anovulatory syndrome in which, as adults, the females have few or no corpora lutea and reduced fertility (Pfeiffer, 1936; Barraclough, 1961; Harris, 1970; Gorski, 1971). The cause of this failure to ovulate has been shown to be masculinization of the LH-controlling mechanisms in the hypothalamus such that the cyclic peak of LH that normally triggers ovulation is absent, as it is in normal males (Feder, 1981a).

Female quail and chickens also have reduced fertility after early (embryonic) administration of oestradiol or testosterone. Treated females, when adult, are less likely to lay eggs, and lay fewer eggs (van Tienhoven, 1957; Glick, 1961; Wentworth, Hendricks \& Sturtevant, 1968; Adkins, 1975; Warner, Cain, Moreng \& Maniscalco, 1977). The reason for this failure to lay is not entirely clear. One possibility is that oviposition is prevented by morphological anomalies caused by the oestrogen treatment. Administration of oestrogen to embryos has been shown to cause retention and

* Reprint requests to E. Adkins-Regan, Uris Hall, Cornell University, Ithaca, NY 14853, U.S.A. 
development of the right Müllerian duct in chickens, resulting in females that have two oviducts (Kaufman, 1956; Erickson \& Pincus, 1966; van Tienhoven, 1968). In one experiment, retention of the right Müllerian duct was observed in female quail hatched from eggs injected with large dosages of oestradiol (Warner et al., 1977). Another possibility, however, is that instead of or in addition to oviduct abnormalities, the females are ovulating less frequently than normal, and are exhibiting the same phenomenon (masculinization of positive feedback hypothalamic mechanisms controlling ovulation) that is seen in rodents. It is important to know whether such masculinization is occurring because, in chickens and quail, embryonic treatment with oestradiol or testosterone causes feminization (demasculinization) of behaviour (and presumably of the neural mechanisms controlling behaviour), rather than causing behavioural masculinization, as it does in mammals (Wilson \& Glick, 1970; Adkins-Regan, 1981; Feder, 1981b).

The purpose of the present experiment was to examine systematically the effect of several dosages of oestradiol benzoate injected into quail eggs during incubation on ovulation, oviduct development, egg laying, and LH levels to determine the cause of reduced fertility.

\section{Materials and Methods}

Animals and procedure. Eggs from breeding quail obtained from Truslow Farms, Chestertown, MD, were incubated at $37.6^{\circ} \mathrm{C}$ and $57 \%$ relative humidity for 16 days, then at $37.2^{\circ} \mathrm{C}$ and $85 \%$ relative humidity until hatching. On Day 10 of incubation (Day 0 is the day the eggs were set in the incubator) eggs were injected with $0.05 \mathrm{ml}$ sesame oil or with $5,10,20$ or $40 \mu \mathrm{g}$ oestradiol benzoate dissolved in $0.05 \mathrm{ml}$ sesame oil. Day 10 falls within the critical period for demasculinization of behaviour in males by embryonic oestradiol benzoate treatment (Adkins, 1979). Injections were made into the albumen of the small end of the egg, and needle holes were sealed with melted paraffin wax.

After hatching, birds were reared on a $16 \mathrm{~h}$ light : $8 \mathrm{~h}$ dark cycle (lights on at $07: 00 \mathrm{~h}$ ). Females were housed in brooders until 28 days after hatching, and individually thereafter in cages measuring $15 \times 20 \times 24 \mathrm{~cm}$.

Sexual maturity (onset of egg laying) normally begins at about 6 weeks of age after hatching in domesticated quail. At 37, 40, 43, 46, 49,52, 55, 58 or 61 days blood samples were taken via wing vein puncture. Each female was bled at one or two of these ages (if bled twice, the bleedings were spaced at least 10 days apart), with random assignment to age at first bleeding. Blood was collected between $09: 30$ and $11: 30 \mathrm{~h}$. Samples were centrifuged at $979 \mathrm{~g}$ for $30 \mathrm{~min}$; plasma was frozen and subsequently assayed for $\mathrm{LH}$.

Beginning at 37 days of age, females were weighed every 4 days, and egg laying was recorded daily. At 61 days of age, all females were killed. Ovaries and oviducts were removed and weighed. Any eggs in the oviduct were removed before weighing. The number of post-ovulatory follicles in each ovary was counted (Kabat, Buss \& Meyer, 1948) and the numbers and the sizes of yolked follicles were recorded. The body cavities were searched for ovulated yolks.

LH assay. The double-antibody radioimmunoassay has been described previously (Johnson \& van Tienhoven, 1980) and is a modification of one originally described and validated for quail by Follett, Scanes \& Cunningham (1972). Iodination was accomplished by the lactoperoxidase method (Bolton, 1977). The assay was accomplished by combining a $25 \mu \mathrm{l}$ sample or standard $(0.4-$ $16.0 \mathrm{ng} / \mathrm{ml})$ and rabbit anti-LH antibody on Day 1. On Day 2, $100 \mu 1^{125} \mathrm{I}$-labelled LH (100 pg) were added, and $100 \mu \mathrm{l}$ anti-rabbit $\gamma$ globulin (second antibody; obtained from Dr W. R. Butler) were added $24 \mathrm{~h}$ later. After incubation for $48 \mathrm{~h}$, tubes were centrifuged, the supernatant decanted, and the pellet counted in a Beckman Gamma 4000 equipped with a DP 5000 data reduction unit. Sensitivity of the assay ranged between 300 and $400 \mathrm{pg} / \mathrm{ml}$. For these samples, the mean betweenand within-assay coefficients of variation were 6.2 and $<10 \%$, respectively. 
Statistical analyses. Data were analysed by $\chi^{2}$ tests or by the appropriate form of analysis of variance followed by (if significant) Duncan's multiple range test.

\section{Results}

Oviposition, mortality and body weight

Oestradiol treatment had no effect on the percentage of eggs hatching. The percentages of birds dying between 37 and 61 days of age were as follows: sesame oil, $0 \%$; oestradiol: $5 \mu \mathrm{g}, 10 \% ; 10 \mu \mathrm{g}$, $12 \% ; 20 \mu \mathrm{g}, 10 \% ; 40 \mu \mathrm{g}, 20 \%$. These birds were excluded from all subsequent analyses. Body weights of birds were not affected by oestradiol benzoate treatment when birds that died were excluded $(\mathrm{F}=2.03 ; \mathrm{df}=4,119 ; P>0.05)$.

Oestradiol benzoate treatment suppressed egg laying in a dose-dependent manner; treated birds were less likely to lay eggs (Text-fig. $1 ; \chi^{2}=28, \mathrm{df}=4, P<0.001$ ) and oestradiol benzoate greatly reduced the proportion of females laying 3 eggs on Days 59-61 (Table $1 ; \chi^{2}=53$, df $=4, P<$ 0.001 ). For those birds that did eventually lay, the age at which the first egg was laid was unaffected (Table 1).

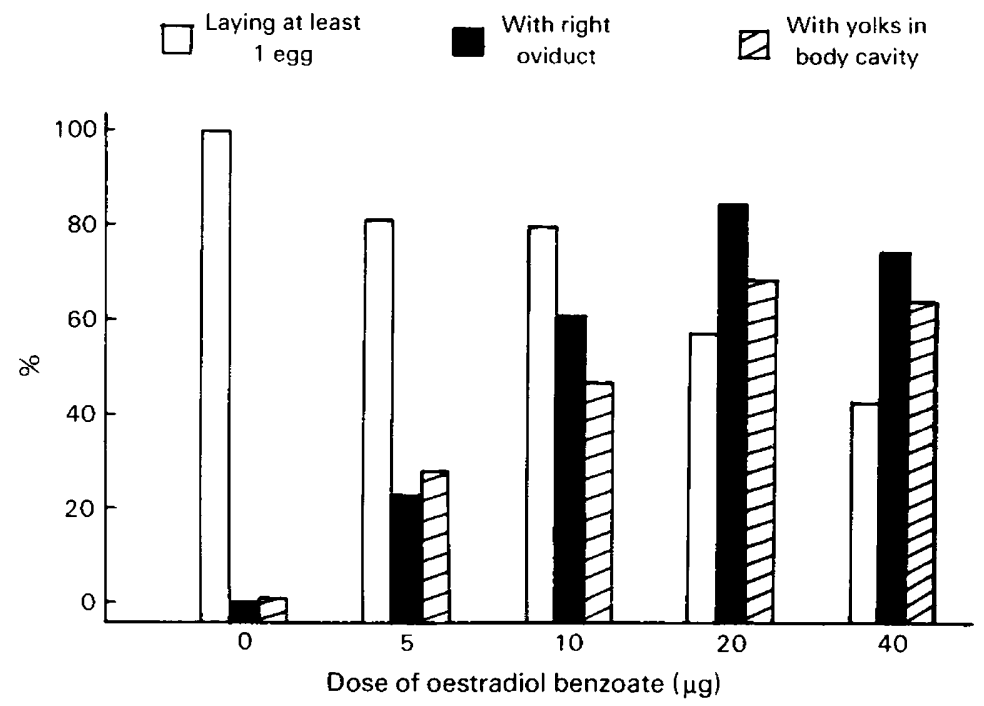

Text-fig. 1. Percentage of females hatched from eggs injected with oestradiol benzoate that ever laid an egg or that had developed a right oviduct or had yolks in the body cavity when examined at 61 days of age. For each group the no. of observations was 15-35.

\section{Ovulation}

The number of large ( $>1 \mathrm{~cm}$ diam.) yolked follicles in the ovaries was not significantly different across the groups (Table 1). Oestradiol benzoate treatment apparently had no effect on ovulation frequency, because the number of post-ovulatory follicles did not differ significantly as a function of treatment (Table $1 ; P>0.05$ for $40 \mu \mathrm{g}$ oestradiol compared with controls). However, oestradiol benzoate treatment did result in a dose-dependent increase in the proportion of birds that had ovulated follicles in the body cavity (Text-fig. $1 ; \chi^{2}=36$, df $=4, P<0.001$ ). 
Emilie F. Rissman et al.

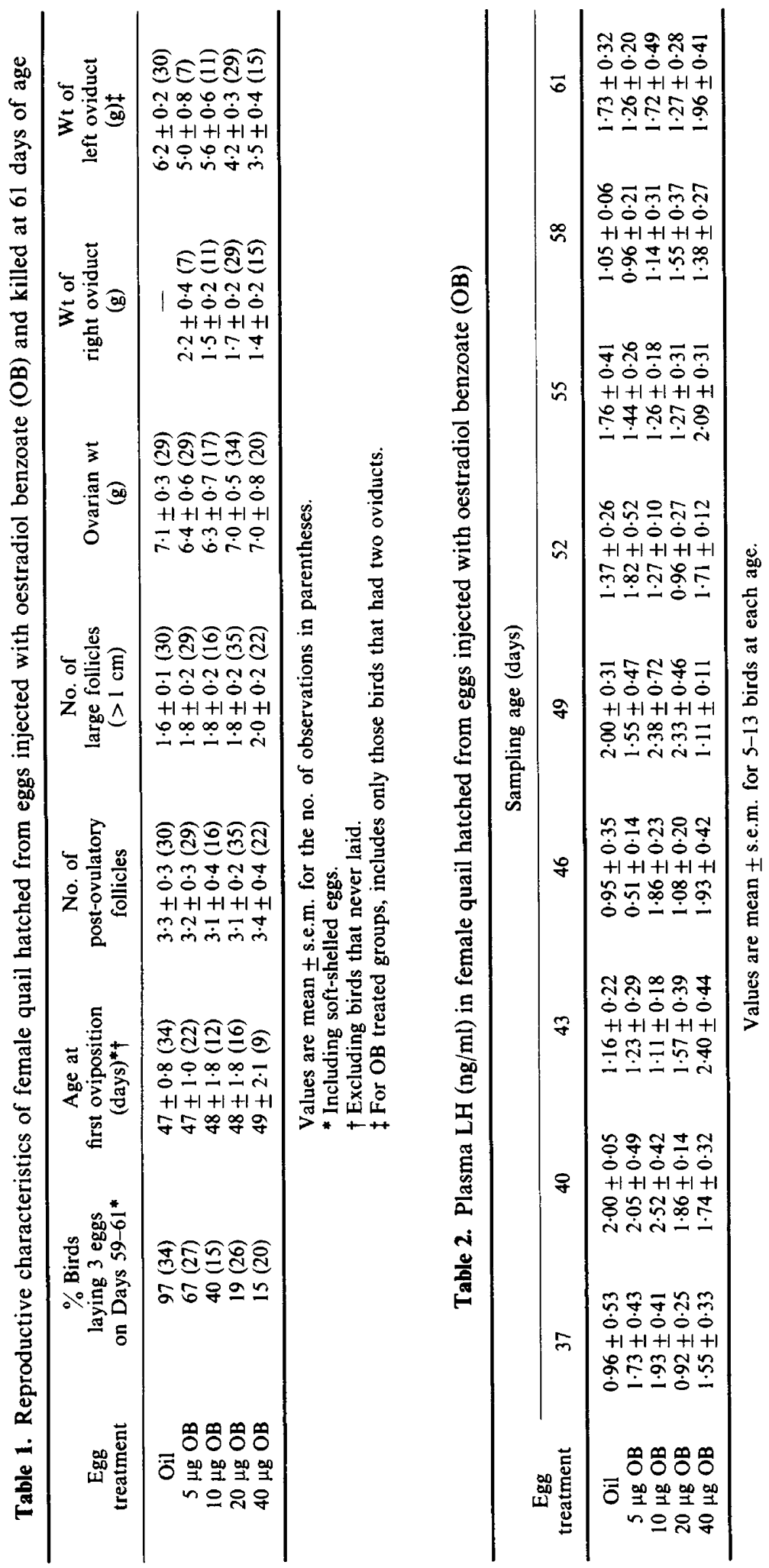




\section{Organ weights}

Oestradiol benzoate had no significant effect on ovarian weight, even at the highest dosage (Table 1), although there was a marked effect on oviducts. In a dose-related manner oestradiol benzoate increased the proportion of females having two oviducts (Text-fig. $1, \chi^{2}=61, \mathrm{df}=4, P$ $<0.001$ ). These right oviducts were less than half the size of left oviducts (Table 1). If left oviducts were compared only for females possessing a single oviduct, then there was no significant effect of oestradiol benzoate on left oviduct weight. However, if females with two oviducts were included, then oestradiol benzoate treatment caused females to have smaller left oviducts (Table $1 ; F=8 \cdot 46$, df $=4,87, P<0.001)$.

\section{LH concentrations}

Oestradiol benzoate treatment had no effect on plasma $\mathrm{LH}$ values (Table $2 ; \mathrm{F}=1 \cdot 7, \mathrm{df}=4$, $225, P>0 \cdot 1$ ). Although $\mathrm{LH}$ concentrations were not higher in older than in younger birds (Table 2) they were nonetheless influenced by physiological stage at sampling ( $\mathrm{F}=2 \cdot 28, \mathrm{df}=8,225, P<$ $0 \cdot 005$ ), due to significantly elevated LH in birds sampled at 40 and 49 days of age (Duncan's multiple range test, $P<0.05$ for each age).

\section{Discussion}

Embryonic treatment with oestradiol benzoate inhibited oviposition in these females, as had been observed previously in quail (Wentworth et al., 1968; Adkins, 1975; Warner et al., 1977). This experiment clearly shows that this effect is due to difficulties at the level of the oviducts rather than to failure to ovulate or failure to maintain normal basal LH levels. The high frequency of yolks in the body cavity in the treated groups suggests that the failure to lay was due to an inability of the ovulated yolks to pass into the left oviduct, either because of the presence of a developed right oviduct or because of a decrease in the size or functional capacity of the left oviduct.

Two previous experiments have also found right oviduct retention in female quail as a function of early oestrogen treatment. In one case (Haffen, 1965) eggs were dipped on Day 4 of incubation into a solution of diethylstilboestrol $(40 \mathrm{mg} / 100 \mathrm{ml}$ ). In the other (Warner et al., 1977) eggs were injected on Day 4 of incubation with 0.1 or $0.5 \mathrm{mg}$ oestradiol benzoate. In the present study, much lower dosages of oestrogen administered much later in incubation still caused right oviduct retention. Left oviducts were normal in weight unless a right oviduct was also present, in which case they were smaller than normal.

At the present time, because of uncertainty about the hormonal mechanisms of right Müllerian duct regression in normal female embryos, it is difficult to explain why oestradiol prevents such regression. In the male chicken, the anti-Müllerian hormone is believed to be non-steroidal (Weniger, Mack \& Holder, 1975), but androgenic steroids have been proposed as the regressing agents for both sexes in quail (Lutz-Ostertag \& Bayle, 1979). In either case, it is possible that oestradiol benzoate suppresses the production of the endogenous gonadal hormones that normally cause regression of the right oviduct (Taber, 1964; Teng \& Teng, 1979). Another possibility is that the oestradiol benzoate acts as an antihormone at the level of the Müllerian duct, blocking either androgens (Teng \& Teng, 1979) or a non-steroidal anti-Müllerian hormone. In an in-vitro study with chickens, testosterone prevented embryonic testes from causing regression of male and female Müllerian ducts (Weniger \& Zeis, 1982). Evidence against a direct stimulatory action of oestradiol benzoate is that the Müllerian duct of chick embryos does not seem to have oestradiol receptors before Day 15 of incubation (Gasc \& Stumpf, 1981).

In quail, the main preovulatory peak of LH occurs about $6 \mathrm{~h}$ before ovulation (Doi, Takai, Nakamura, \& Tanabe, 1980), which in turn occurs 15 min-2 h after oviposition (Opel, 1966). In our 
laboratory birds generally oviposit between $16: 00$ and $17: 00 \mathrm{~h}$, and so the preovulatory LH peak for our females should have occurred during the period of sampling. Not only were LH levels, as measured here, unaffected by embryonic oestradiol benzoate treatment, but ovulation appeared to occur normally in all groups.

Urbanski \& Follett (1982) have shown that plasma LH concentrations differ in male and female quail; for example, if males and females are gonadectomized and housed on a long photoperiod, LH values are $20-25 \mathrm{ng} / \mathrm{ml}$ in males and $10-15 \mathrm{ng} / \mathrm{ml}$ in females. It is not yet known (although the data of Urbanski \& Follett (1982) are suggestive) whether the hypothalamic mechanisms controlling LH release are dimorphic in quail (or other birds), as has been shown for rodents. The present study provides some indirect evidence that oestradiol benzoate does not masculinize the hypothalamus of the female quail. Although oviposition was suppressed, ovulation was not. Therefore, the low fertility caused by early exposure to oestradiol in birds and mammals, while superficially similar, is fundamentally different with respect to its cause in the two groups.

This study was supported by NSF grant BNS 76-24308 to E.A.-R. and an NSF graduate fellowship to E.R. We thank Dr A. van Tienhoven for helpful discussions of the experiment.

\section{References}

Adkins, E.K. (1975) Hormonal basis of sexual differentiation in the Japanese quail. J. comp. Physiol. Psychol. 89, $61-71$.

Adkins, E.K. (1979) Effect of embryonic treatment with estradiol or testosterone on sexual differentiation of the quail brain: critical period and dose-response relationships. Neuroendocrinology 29, 178-185.

Adkins-Regan, E. (1981) Early organizational effects of hormones: an evolutionary perspective. In Neuroendocrinology of Reproduction: Physiology and Behavior, pp. 159-228. Ed. N. T. Adler. Plenum Press, New York.

Barraclough, C.A. (1961) Production of anovulatory, sterile rats by single injections of testosterone propionate. Endocrinology 34, 62-69.

Bolton, A.E. (1977) Radioiodination Techniques, Review 18, pp. 55-56. Amersham Corp., Arlington Heights, IL.

Doi, O., Takai, T., Nakamura, T. \& Tanabe, Y. (1980) Changes in the pituitary and plasma LH, plasma and follicular progesterone and estradiol, and plasma testosterone and estrone concentrations during the ovulatory cycle of the quail (Coturnix coturnix japonica). Gen. comp. Endocr. 41, 156-163.

Erickson, A.E. \& Pincus, G. (1966) Modification of embryonic development of reproductive and lymphoid organs in the chick. J. Embryol. exp. Morph. 16, 211-229.

Feder, H.H. (1981a) Hormonal actions on the sexual differentiation of the genitalia and the gonadotropinregulating systems. In Neuroendocrinology of Reproduction: Physiology and Behavior, pp. 89-126. Ed. N. T. Adler. Plenum Press, New York.

Feder, H.H. (1981 b) Perinatal hormones and their role in the development of sexually dimorphic behaviors. In Neuroendocrinology of Reproduction: Physiology and Behavior, pp. 127-157. Ed. N. T. Adler. Plenum Press, New York.

Follett, B.K., Scanes, C.G. \& Cunningham, F.J. (1972) A radioimmunoassay for avian luteinizing hormone. $J$. Endocr. 52, 359-378.

Gasc, J.M. \& Stumpf, W.E. (1981) Sexual differentiation of the urogenital tract in the chicken embryo: autoradiographic localization of sex-steroid target cells during development. J. Embryol. exp. Morph. 63, 207-281.

Glick, B. (1961) The reproductive performance of birds hatched from eggs dipped in male hormone solutions. Poult. Sci. 40, 1408, Abstr.

Gorski, R.A. (1971) Gonadal hormones and the perinatal development of neuroendocrine function. In Frontiers in Neuroendocrinology, pp. 237-290. Eds $\mathbf{L}$. Martini \& W. F. Ganong. Oxford University Press, New York.

Haffen, K. (1965) Intersexualité chez la Caille (Coturnix coturnix). Obtention d'un cas de ponte ovulaire par un mâle génétique. C.r. hebd. Séanc. Acad. Sci. Paris D 261, 3876-3879.

Harris, G.W. (1970) Hormonal differentiation of the developing central nervous system with respect to patterns of endocrine function. Phil. Trans. $R$. Soc. Lond. (Biol.) 259, 165-177.

Johnson, A.L. \& van Tienhoven, A. (1980) Plasma concentrations of six steroids and LH during the ovulatory cycle of the hen, Gallus domesticus. Biol. Reprod. 23, 386-393.

Kabat, C., Buss, I.O. \& Meyer, R.K. (1948) The use of ovulated follicles in determining eggs laid by the ringnecked pheasant. $J$. Wildl. Mgmt 12, 399-416.

Kaufman, L. (1956) Experiments on sex modification in cocks during their embryonal development. Wld Poult. Sci. J. 12, 41-42.

Lutz-Ostertag, Y. \& Bayle, D. (1979) Dosages radioimmunologiques de la testostérone et de la dihydrotestostérone dans les canaux de Müller d'embryons de cailles témoins et injectés de propionate de testostérone. Archs Anat. microsc. Morph. exp. 68, $29-42$. 
Opel, H. (1966) The timing of oviposition and ovulation in the quail (Coturnix coturnix japonica). Br. Poult. Sci. 7, $29-38$.

Pfeiffer, C.A. (1936) Sexual differences of the hypophyses and their determination by the gonads. Am.J. Anat. 58, 195-206.

Taber, E. (1964) Intersexuality in birds. In Intersexuality in Vertebrates Including Man, pp. 285-310. Eds C. N. Armstrong \& A. J. Marshall. Academic Press, London.

Teng, C.S. \& Teng, C.T. (1979) Prenatal effect of the estrogenic hormone on embryonic genital organ differentiation. In Ontogeny of Receptors and Reproductive Hormone Action, pp. 421-440. Eds T. H. Hamilton, J. H. Clark \& W. A. Sadler. Raven Press, New York.

Urbanski, H.F. \& Follett, B.K. (1982) Sexual differentiation of the photoperiodic response in Japanese quail. J. Endocr. 92, 279-282.

van Tienhoven, A. (1957) A method of "controlling sex" by dipping of eggs in hormone solutions. Poult. Sci. 36, 628-632.

van Tienhoven, A. (1968) Reproductive Physiology of Vertebrates. Saunders, Philadelphia.
Warner, R.L., Cain, J.R., Moreng, G.R. \& Maniscalco, V.J. (1977) Reproductive organs and behavior of Japanese quail following treatment of embryos with steroid and antisteroids. Anat. Rec. 187, 742, Abstr.

Weniger, J.-P. \& Zeis, A. (1982). Actions antagonistes de la testostérone et de l'hormone anti-Müllérienne sur le canal de Müller d'embryon de poulet en culture in vitro. Archs Anat. microsc. Morph. exp. 71, 99106.

Weniger, J.-P., Mack, G. \& Holder, F. (1975) L'hormone responsable de la régression des canaux de Müller chez l'embryon de poulet mâle n'est pas un androgène. C. r. hebd. Séanc. Acad. Sci. Paris D 280, 18891891.

Wentworth, B.C., Hendricks, B.G. \& Sturtevant, J. (1968) Sterility induced in Japanese quail by spray treatment of eggs with mestranol. J. Wildl. Mgmt 32, 879887.

Wilson, J.A. \& Glick, B. (1970) Ontogeny of mating behavior in the chicken. Am. J. Physiol. 218, 951955.

Received 22 September 1983 